\title{
EFFECT OF IMMUNOSUPPRESSIVE AGENTS ON HUMAN T AND B LYMPHOBLASTS
}

\author{
Irene S. Kazmers, Peter E. Daddona, A. Paulette Dalke and \\ William N. KelleY* \\ Departments of Internal Medicine and Biological Chemistry, University of Michigan Medical Center, \\ Ann Arbor, MI 48109, U.S.A.
}

(Received 18 May 1982; accepted 11 August 1982)

\begin{abstract}
We have studied the effects of various immunosuppressive drugs on the growth of humanderived T (MOLT-4) and B (MGL-8) lymphoblasts. In addition, we have examined whether the lymphotoxic effect of any of these drugs could be attributed to inhibition of either adenosine deaminase (ADA) or purine nucleoside phosphorylase (PNP). Results indicated that $1-\beta$-D-arabinofuranosylcytosine (Ara-C), methotrexate and chlorambucil were four to seven times more toxic for $T$ than for $B$ cells, while azathioprine, 6-thioguanine, 6-mercaptopurine, and 5-fluorouracil were highly toxic for both $\mathrm{T}$ and $\mathrm{B}$ cells. Cyclophosphamide and oxisuran were lymphotoxic only at concentrations exceeding $300 \mu \mathrm{M}$. Deoxyadenosine $(50 \mu \mathrm{M})$, deoxyguanosine $(10 \mu \mathrm{M})$ and deoxycoformycin $(10 \mu \mathrm{M})$ failed to enhance $\mathrm{T}$ cell toxicity when individually combined with each drug. None of the drugs tested inhibited T or B lymphoblast ADA or PNP activity. With the exception of Ara-C, neither dATP nor dGTP accumulated in $T$ lymphoblasts incubated in the presence of any of the drugs. We conclude that the cell culture system used in this investigation is useful for identifying lymphotoxic and $\mathrm{T}$ cell-specific immunosuppressive agents. However, none of the drugs studied appeared to function as an inhibitor of, or a competitive substrate for, either ADA or PNP.
\end{abstract}

The exact mechanisms by which many clinically useful immunosuppressive drugs produce immunologic compromise are not well understood, in spite of knowledge of their structures and many of their metabolic, cytotoxic and mutagenic effects. This lack of understanding is due, in part, to inadequate systems being available for elucidating biochemical mechanisms of immunoregulation, and to the relatively primitive current concepts of biological immune system control.

The discoveries of two heritable immune disorders associated with specific enzyme defects may provide clues to the nature of the control of immune function at the biochemical level. Adenosine deaminase (EC 3.5.4.4) (ADA), an enzyme in the purine catabolic pathway, catalyzes the conversions of deoxyadenosine to deoxyinosine and of adenosine to inosine. A genetic deficiency of ADA causes severe combined immunodeficiency disease, with profound cellular immune dysfunction and variable humoral immunosuppression $[1,2]$. Purine nucleoside phosphorylase (EC 2.4.2.1) (PNP) is another purine degradative enzyme which is responsible for the conversions of guanosine, inosine, and their $2^{\prime}$-deoxy derivatives to their respective purine bases. An inherited deficiency of PNP in man is characterized by profound cellular immune dysfunction with intact humoral immunity $[3,4]$. With a deficiency of either ADA or PNP enzyme activity the respective deoxynucleoside substrate, deoxyadenosine or deoxyguanosine, is converted to its corresponding deoxynucleoside triphosphate (dATP or dGTP) (Fig. 1), as demonstrated in the erythrocytes of affected individuals

* Author to whom correspondence should be addressed.
[5-7]. The resultant high level of dATP or dGTP appears to cause cytotoxicity primarily through feedback inhibition of ribonucleotide reductase, which limits the reduction of nucleoside diphosphates to their corresponding $2^{\prime}$-deoxy derivatives, and thereby decreases the rate of DNA synthesis $[8,9]$.

An in vitro cell culture system which reproduces, under the appropriate conditions, both the biochemical changes and the selective lymphotoxicity observed in the ADA and PNP deficiency diseases has been described [10]. A low concentration of deoxyadenosine in the presence of an ADA inhibitor leads to the accumulation of dATP and toxicity in cultured $\mathrm{T}$ lymphoblasts but not in B lymphoblasts, thus mimicking ADA deficiency disease [10]. The addition of deoxyguanosine $(50 \mu \mathrm{M})$ to culture medium leads to a selective increase in the level of dGTP and toxicity for T cells but not for B cells, analogous to changes observed in PNP deficiency disease. B cells may be protected from dATP and dGTP accumulation by their high deoxynucleotidedegrading enzyme activity [11-13]. The usefulness of this $T$ and $B$ cell system for elucidating mechanisms of lymphocytotoxicity related to the inhibition of ADA or PNP has been established $[8,14]$.

In the present study, we have used this lymphoblast tissue culture system to study a selected group of immunosuppressive drugs. The drugs were chosen from a broad range of pharmacologic classes including alkylating agents, purine and pyrimidine analogues and folic acid analogues. All of these drugs have demonstrated suppressive effects on immune function in humans, animal models and/or in vitro systems of cellular and/or humoral immunity [15-21] and, with the exception of oxisuran, are all in current 


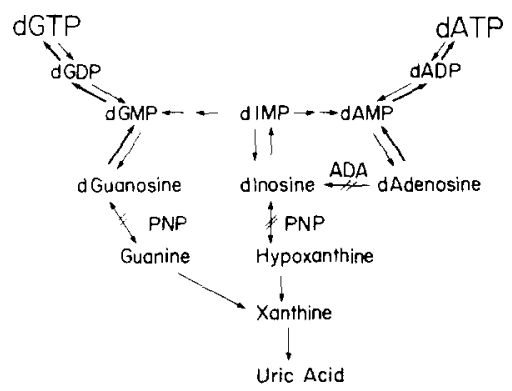

Fig. 1. Pathways of deoxypurine metabolism. Slashes indicate the reaction(s) blocked in purine nucleoside phosphorylase (PNP) and adenosine deaminase (ADA) deficiency disease.

clinical usage. Although the mechanism of action of cytotoxicity has been established for certain of these study drugs, the question of why they also cause immune dysfunction has not been answered at the biochemical level. We have investigated whether any of these drugs appears to mimic the mechanism of immunosuppression in ADA or PNP immunodeficiency disease by demonstrating selective $\mathrm{T}$ lymphoblast cytotoxicity caused either by the inhibition of ADA or PNP activity (which might not be predictable based solely on chemical structure) or by otherwise leading to the accumulation of toxic levels of dATP or dGTP.

\section{MATERIALS AND METHODS}

\section{Materials}

The radioisotopes $\left[8{ }^{14} \mathrm{C}\right]$ adenosine $(55 \mathrm{mCi} /$ mmole) and $\left[8-{ }^{14} \mathrm{C}\right]$ inosine $(52 \mathrm{mCl} / \mathrm{mmole})$ were obtained from Amersham/Searle (Arlington Heights, IL). $\left[8-{ }^{14} \mathrm{C}\right]$ Adenine $(62 \mathrm{mCi} / \mathrm{mmole})$ was purchased from the New England Nuclear Corp. (Boston, MA). Methotrexate, azathioprine, 1- $\beta$-Darabinofuranosylcytosine (Ara-C), chlorambucil, cyclophosphamide, 2'-deoxyadenosine, 2'-deoxyguanosine, 5-fluorouracil, 6-mercaptopurine, 2amino-6-mercaptopurine (6-thioguanine), dATP and dGTP were purchased from the Sigma Chemical Co. (St. Louis, MO). Deoxycoformycin (Pentostatin) and 2-[(methylsulfinyl)acetyl]pyridine(oxisuran) were gifts from the Warner-Lambert Co. (Ann Arbor, MI). RPMI 1640 medium and heatinactivated horse serum were obtained from the Grand Island Biological Co. (Grand Island, NY). All other materials used were of the highest quality commercially available. The MOLT-4 lymphoblast cell line was originally derived from a patient with acute lymphoblastic leukemia and the MGL-8 lymphoblast cell line was derived from a normal individual as previously reported [10].

\section{Methods}

Cell culture conditions. Each lymphoblast cell line was maintained in RPMI 1640 medium containing $10 \%$ heat-inactivated horse serum and $2 \mathrm{mM}$ glutamine. All lymphoblast growth curves were initiated at a cell density of approximately $2.5 \times 10^{5}$ cells $/ \mathrm{ml}$.
Viable cells were counted at 24-hr intervals using a hemocytometer to assess cell growth, with trypan blue dye exclusion used as an index of viability.

Each immunoregulatory drug studied was added over a broad range of concentrations to both MOLT -4 and MGL- 8 cell cultures, and the effect on cell growth was monitored over a 72 -hr culture period. To establish the cytostatic drug concentration, defined as the concentration at which no net growth or loss of cell viability occurred over the 72-hr study period, a series of growth studies was conducted for each drug using progressively narrower concentration ranges until the cytostatic concentration was determined. The cytotoxic drug concentration was defined as that concentration resulting in a $50 \%$ decrease in the initial concentration of viable cells over the 72 -hr culture period. Using the concentration of drug which was found to be cytostatic for T lymphoblasts, the effect of each drug on $T$ lymphoblast growth was studied in combination with either deoxyadenosine $(50 \mu \mathrm{M})$, deoxyguanosine $(10 \mu \mathrm{M})$, or deoxycoformycin $(10 \mu \mathrm{M})$. As positive controls, the growth of $\mathrm{T}$ cells in the presence of deoxyadenosine $(50 \mu \mathrm{M})$ with deoxycoformycin $(10 \mu \mathrm{M})$ or deoxyguanosine $(50 \mu \mathrm{M})$ alone was studied in parallel with these experiments.

Enzyme assays. ADA and PNP were assayed in MOLT-4 lymphoblast cell extracts using previously described radiochemical techniques $[22,23]$. MOLT-4 cells were harvested, washed in $50 \mathrm{mM}$ $\mathrm{NaP}_{i}, \mathrm{pH} 7.4$, containing $154 \mathrm{mM} \mathrm{NaCl}$ (PBS) and lysed by freezing and thawing five times. The cell extract was dialyzed $1 / 1000(\mathrm{v} / \mathrm{v})$ against $10 \mathrm{mM}$ Tris- $\mathrm{HCl}$, pH 7.4, overnight and centrifuged at $100,000 \mathrm{~g}$ for $20 \mathrm{~min}$. The inhibitory effect of each drug on the enzymatic activity of ADA or PNP in dialyzed MOLT-4 cell extracts was assessed by assaying ADA and PNP activities individually using $K_{m}$ concentrations of radioactive substrates adenosine or inosine $(0.06 \mathrm{mM})$, respectively, in the presence of a drug concentration determined to be toxic to MOLT-4 cells in culture. The apparent $K_{m}$ values for deoxyadenosine and both deoxyguanosine and deoxyinosine for the respective enzymes, ADA and PNP, are equivalent to those of the ribonucleoside substrates used in this assay system $[24,25]$.

\section{Measurement of $d A T P$ and $d G T P$ levels in $T$ and $B$ lymphoblasts}

Extraction of acid-soluble nucleotides. $\mathrm{T}$ (MOLT-4) or B (MGL-8) lymphoblasts were suspended at a final cell density of $6 \times 10^{5}$ cells $/ \mathrm{ml}$ in RPMI 1640 media containing drugs with or without deoxyadenosine $(50 \mu \mathrm{M})$ or deoxyguanosine $(10 \mu \mathrm{M})$. The drug concentrations used were greater than the cytotoxic concentrations of the drugs as defined above. Cells were harvested after an 18-hr incubation at $37^{\circ}$ and centrifuged $(800 \mathrm{~g})$ for $5 \mathrm{~min}$ at room temperature. The cell pellet was then washed once with $1.5 \mathrm{ml}$ of ice-cold PBS.

Using a modification of the extraction method of Khym [26], the washed cells were suspended at a ratio of $1 \times 10^{8}$ cells to $1.0 \mathrm{ml}$ of $6 \%$ trichloroacetic acid (TCA) which contained $\left[8-{ }^{14} \mathrm{C}\right]$ adenine $\left(8 \times 10^{5} \mathrm{cpm} / \mathrm{ml}\right)$ to serve as an internal standard for 
calculating the dilution of the sample during the extraction and subsequent periodate treatment. Each sample was mixed for $1 \mathrm{~min}$ and placed on ice for $30 \mathrm{~min}$. After centrifugation $(800 \mathrm{~g})$ for $2 \mathrm{~min}$ at room temperature, the acid-soluble supernatant fraction was neutralized by mixing for 1 min with an equal volume of $0.5 \mathrm{M}$ tri- $N$-octyl amine in Freon. After centrifugation, the aqueous upper layer was removed and stored at $-70^{\circ}$ until periodate treated.

Destruction of ribonucleotides by periodate oxidation. Prior to the analysis of dATP and dGTP in cell extracts by high performance liquid chromatography (HPLC), the ribonucleotides were destroyed by treatment with periodate and methylamine by a modification of the method of Garrett and Santi [27]. To each $100 \mu \mathrm{l}$ of cell extract, $10 \mu \mathrm{l}$ of $0.5 \mathrm{M}$ sodium periodate and $12 \mu \mathrm{l}$ of $4 \mathrm{M}$ methylamine- $\mathrm{P}_{\mathrm{i}}, \mathrm{pH} 7.5$, were added. The reaction mixture was then incubated at $37^{\circ}$ for $30 \mathrm{~min}$. After adding $8 \mu \mathrm{l}$ of $1 \mathrm{M}$ rhamnose, the extracts were frozen in dry ice-ethanol and stored at $-70^{\circ}$. The samples were then filtered through a $0.45 \mu \mathrm{m}$ regenerated cellulose membrane (Bioanalytical Systems, Inc.) prior to HPLC analysis.

Quantitation of dATP and dGTP. A Waters Associates High Performance Liquid Chromatograph, equipped with a U6K injector, two model 6000 A solvent delivery systems, an M440 fixed wavelength detector $(254 \mathrm{~nm})$, an M450 variable wavelength detector, an M720 systems controller and an M620 data module, was used. Deoxyribonucleoside triphosphates in the prepared cell extracts were resolved by isocratic elution on a Whatman Partisil SAX-10 anion exchange column $(4.6 \times 250 \mathrm{~mm})$ with $2 \%$ spectrophotometric grade acetonitrile in $0.4 \mathrm{M}$ ammonium phosphate, $\mathrm{pH} 3.25$, at a flow rate of $2 \mathrm{ml} / \mathrm{min}$ [27]. The compounds were identified by their retention times and by the ratios of their peak heights at 280 and $254 \mathrm{~nm}$ relative to standards and were quantitated by comparing their peak heights (manually measured) at $254 \mathrm{~nm}$ with the peak heights of standard solutions.

\section{RESULTS}

In our cell culture system, the addition of the ADA inhibitor, deoxycoformycin $(10 \mu \mathrm{M})$, to cul-

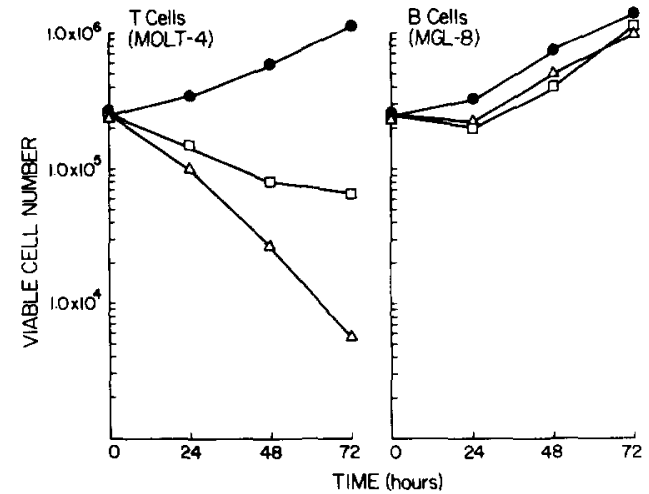

Fig. 2. Selected in vitro cytotoxicity of deoxynucleosides. The toxic effect of the combination of deoxyadenosine $(50 \mu \mathrm{M})$ and deoxycoformycin $(10 \mu \mathrm{M})(\Delta-\Delta)$ on cultured $T$ cells $(N=4)$ is compared to that in $B$ cells $(\mathrm{N}=2)$ and the toxic effect of deoxyguanosine $(50 \mu \mathrm{M})$ $(\square-[]$ ) on cultured $T$ cells $(N=14)$ is compared to that in $\mathrm{B}$ cells $(\mathrm{N}=3)$. Control growth $(-)$ is represented for both $T$ cells $(N=18)$ and $B$ cells $(N=15)$.

ture meulum in the presence of deoxyadenosine $(50 \mu \mathrm{M})$ was markedly toxic to T (MOLT-4) but not B (MGL-8) lymphoblasts (Fig. 2). This selective T cell toxicity correlated with the striking accumulation of dATP in the treated T cells, but not in the B cells (Table 1). Similarly, the addition of deoxyguanosine $(50 \mu \mathrm{M})$ to culture medium was extremely toxic to T but not B lymphoblasts (Fig. 2), and this selective effect correlated with the accumulation of dGTP in extracts of the T but not the B cells (Table 1). Neither T nor B cell growth was affected by the individual addition of either deoxyadenosine $(50 \mu \mathrm{M})$, deoxycoformycin $(10 \mu \mathrm{M})$, or deoxyguanosine $(10 \mu \mathrm{M})$.

The cytostatic and cytotoxic concentrations for each of the immunosuppressive drugs studied with respect to the growth of $\mathrm{T}$ and $\mathrm{B}$ lymphoblasts are shown in Table 2. Ara-C, methotrexate, 6-thioguanine, 6-mercaptopurine, 5-fluorouracil, chlorambucil, and azathioprine were highly toxic to both the $T$ and $B$ cell lines at concentrations in the culture media of less than $26 \mu \mathrm{M}$. Of these, Ara-C, methotrexate and chlorambucil were more toxic for $T$ than B cells. Oxisuran and cyclophosphamide were

Table 1. Intracellular dATP and dGTP levels of T and B cells incubated with deoxyadenosine and deoxycoformycin or with deoxyguanosine*

\begin{tabular}{|c|c|c|c|c|c|}
\hline & & \multicolumn{2}{|c|}{$\begin{array}{c}\mathrm{dATP} \\
\text { (pmoles } / 10^{6} \text { cells) }\end{array}$} & \multicolumn{2}{|c|}{$\begin{array}{c}\text { dGTP } \\
\text { (pmoles } / 10^{6} \text { cells) }\end{array}$} \\
\hline & & $\begin{array}{l}\text { MOLT-4 } \\
\text { T cells }\end{array}$ & $\begin{array}{l}\text { MGL-8 } \\
\text { B cells }{ }^{\dagger}\end{array}$ & $\begin{array}{l}\text { MOLT-4 } \\
\text { T cells }\end{array}$ & $\begin{array}{l}\text { MGL-8 } \\
\text { B cells }\end{array}$ \\
\hline Control & & $44 \pm 6(9) \ddagger$ & 7 & $17 \pm 5(9)$ & $<2$ \\
\hline $\begin{array}{l}\text { Deoxyadenosine, } \\
\text { and deoxycoformycin } \\
\text { Deoxyguanosine }\end{array}$ & $\begin{array}{l}50 \mu \mathrm{M} \\
10 \mu \mathrm{M} \\
50 \mu \mathrm{M}\end{array}$ & $\begin{array}{l}909 \pm 239(8) \\
164 \pm 43(8)\end{array}$ & $\begin{array}{l}32 \\
13\end{array}$ & $\begin{array}{c}8 \pm 4(6) \\
213 \pm 107(8)\end{array}$ & $\begin{array}{l}<2 \\
<2\end{array}$ \\
\hline
\end{tabular}

* MOLT-4 and MGL-8 lymphoblasts were incubated for $18 \mathrm{hr}$ with and without the indicated additives, and the dATP and dGTP levels in the cell extracts were determined using high performance liquid chromatography as described in Methods.

$\dagger$ B cell results confirm previous determinations [10].

$\ddagger$ Mean \pm 1 S.D.; parentheses indicate the number of extracts analyzed for each determination. 
Table 2. Cytostatic and cytotoxic drug concentrations for $\mathrm{T}$ and $\mathrm{B}$ lymphoblasts*

\begin{tabular}{lccccc}
\hline & \multicolumn{2}{c}{$\begin{array}{c}\text { MOLT-4 } \\
\text { T lymphoblast }\end{array}$} & & \multicolumn{2}{c}{$\begin{array}{c}\text { MGL-8 } \\
\text { B lymphoblast }\end{array}$} \\
\cline { 2 - 3 } \cline { 5 - 6 } Drug & $\begin{array}{c}\text { Cytostatic } \\
(\mu \mathrm{M})\end{array}$ & $\begin{array}{c}\text { Cytotoxic } \\
(\mu \mathrm{M})\end{array}$ & & $\begin{array}{c}\text { Cytostatic } \\
(\mu \mathrm{M})\end{array}$ & $\begin{array}{c}\text { Cytotoxic } \\
(\mu \mathrm{M})\end{array}$ \\
\hline Ara-C & 0.01 & 0.05 & & 0.05 & 0.20 \\
Methotrexate & 0.03 & 0.04 & & 0.03 & 0.3 \\
6-Thioguanine & 0.24 & 1.0 & & 0.22 & 0.25 \\
6-Mercaptopurine & 2.3 & 3.0 & & 2.9 & 4.0 \\
5-Fluorouracil & 3.8 & 16.1 & & 2.3 & 14.2 \\
Chlorambucil & 4.9 & 6.9 & & 19.7 & 17.8 \\
Azathioprine & 14.4 & 26 & & 14.4 & 11,202 \\
Oxisuran & 683 & 4,098 & 5,464 & 14,147 \\
Cyclophosphamide & 3,380 & 5,262 & 13,405 & \\
\hline
\end{tabular}

* The cytostatic and cytotoxic concentrations of each drug for $\mathrm{T}$ and $\mathrm{B}$ lymphoblasts were determined as described in Methods. Each value represents 1-2 determinations.

cytotoxic only at concentrations exceeding $300 \mu \mathrm{M}$ and appeared to be more toxic for the $\mathrm{T}$ than the $B$ cells, as most clearly demonstrated by comparison of their cytostatic concentrations.

The effects of the immunosuppressive drugs on MOLT-4 lymphoblast ADA and PNP activities were determined by in vitro enzyme assays. None of the drugs tested was found to cause appreciable inhibition of either ADA or PNP activity under the assay conditions at a concentration toxic to $\mathrm{T}$ cells.

The dATP and dGTP content of MOLT-4 cells incubated with those drugs which were selectively more toxic for $\mathrm{T}$ than $\mathrm{B}$ lymphoblasts and with those which were highly lymphotoxic was determined, as

Table 3. Effect of immunosuppressive drugs on the levels of dATP and dGTP in MOLT-4 T lymphoblasts*

\begin{tabular}{|c|c|c|c|}
\hline Drug & $\begin{array}{l}\text { Conc } \\
(\mu \mathrm{M})\end{array}$ & $\begin{array}{c}\mathrm{dATP} \dagger \\
\text { (pmoles } / 10^{6} \text { cells) }\end{array}$ & $\begin{array}{c}\mathrm{dGTP}^{+} \\
\text {(pmoles } / 10^{6} \text { cells) }\end{array}$ \\
\hline None & & $44 \pm 6 \ddagger(9)$ & $17 \pm 5(9)$ \\
\hline +dAdo & & $67 \pm 13(5)$ & $20 \pm 3(5)$ \\
\hline +dGuo & & $50 \pm 7(5)$ & $19 \pm 4(5)$ \\
\hline Ara-C & 18 & 178 & 60 \\
\hline$+\mathrm{dAdo}$ & & 263 & 53 \\
\hline$+\mathrm{dGuo}$ & & 136 & 42 \\
\hline Methotrexate & 66 & 14 & 2 \\
\hline +dAdo & & 99 & 7 \\
\hline +dGuo & & 28 & 7 \\
\hline 6-Thioguanine & 12 & 15 & 5 \\
\hline + dAdo & & 66 & 18 \\
\hline +dGuo & & 20 & 11 \\
\hline 6-Mercaptopurine & 9 & 12 & 6 \\
\hline+ dAdo & & 74 & 21 \\
\hline +dGuo & & 11 & 8 \\
\hline Chlorambucil & 20 & 41 & 16 \\
\hline$+\mathrm{dAdo}$ & & 67 & 17 \\
\hline +dGuo & & 42 & 16 \\
\hline Azathioprine & 72 & 23 & 12 \\
\hline + dAdo & & 52 & 15 \\
\hline + dGuo & & 22 & 11 \\
\hline Oxisuran & 5450 & 51 & 24 \\
\hline +dAdo & & 25 & 15 \\
\hline +dGuo & & 27 & 16 \\
\hline Cyclophosphamide & 1530 & 25 & 11 \\
\hline+ dAdo & & 23 & 7 \\
\hline + dGuo & & 14 & 7 \\
\hline
\end{tabular}

* The levels of dATP and dGTP in acid-soluble, periodate-methylamine-treated extracts of MOLT-4 lymphoblasts, incubated with selected drugs with and without $50 \mu \mathrm{M}$ deoxyadenosine (dAdo) or $10 \mu \mathrm{M}$ deoxyguanosine (dGuo), were determined as described in Methods.

$\dagger$ Except as indicated in parentheses, 1-2 determinations of dATP and dGTP were performed for each drug-additive combination.

$\ddagger$ Mean \pm 1 S.D. 
described in Methods. As shown in Table 1, incubation of MOLT-4 cells with deoxycoformycin $(10 \mu \mathrm{M})$ plus deoxyadenosine $(50 \mu \mathrm{M})$ or with deoxyguanosine $(50 \mu \mathrm{M})$, which represented positive controls for this model system, resulted in a 28 -fold increase in dATP and a 22 -fold increase in dGTP respectively. However, with one exception, none of the drugs tested at concentrations above those which were cytotoxic for $\mathrm{T}$ cells, either alone or with additives, caused greater than a 2 -fold increase in the level of either dATP or dGTP over control values. The exception was Ara-C, which caused 3to 5-fold increases in intracellular dATP and/or dGTP both alone and with additives (Table 3 ).

\section{DISCUSSION}

The purpose of this investigation was to determine whether any of a variety of immunosuppressive drugs inhibited the growth of $\mathrm{T}$ or $\mathrm{B}$ lymphoblasts in culture and to establish whether the mechanism of toxicity might be directly related either to ADA or PNP inhibition or to other mechanisms leading to the accumulation of dATP or dGTP. We have compared the growth of $\mathrm{T}$ and $\mathrm{B}$ lymphoblasts cultured in the presence of these drugs, looking for $T$ cellspecific toxicity, as observed in cell culture models of the ADA and PNP deficiency diseases. In addition, we studied the effects on $T$ and $B$ cell growth of low concentrations of deoxyadenosine, deoxyguanosine, and deoxycoformycin, in combination with the drugs under study, in order to test for potentiation of $T$ cell toxicity under these conditions. This phase of the study was necessitated, in part, because known potent inhibitors of ADA such as erythro-9-(2-hydroxy-3-nonyl)adenine and deoxycoformycin require the presence of the added ADA substrate, deoxyadenosine, to manifest their toxicity for cultured T lymphoblasts [10], just as the PNP inhibitor, 8-aminoguanosine, requires the presence of deoxyguanosine to exert its toxic effect on T cells [14]. Furthermore, each drug was tested directly to determine if it was capable of inhibiting either ADA or PNP activity in vitro using a concentration of the drug which was cytotoxic. Finally, we examined the dATP and dGTP content of T cells exposed to those drugs which were found to cause selective $T$ cell toxicity as well as to those drugs which were highly lymphotoxic, to determine whether the drug-related toxicity could be attributed to the accumulation of a deoxynucleoside triphosphate as seen in ADA or PNP deficiency states.

Our results indicated that Ara-C, methotrexate, 6-thioguanine, 6-mercaptopurine, and 5-fluorouracil were highly toxic to $\mathrm{T}$ and $\mathrm{B}$ lymphoblasts at concentrations in the cell culture media of $16 \mu \mathrm{M}$ or less. These drug concentrations were within the range of their previously reported human plasma levels determined after the administration of therapeutic doses [28-35]. Of these drugs, Ara-C and methotrexate were shown to be selectively more toxic for $T$ than $\mathrm{B}$ cells. When deoxyadenosine, deoxyguanosine, or deoxycoformycin was added to $\mathrm{T}$ lymphoblast cultures with either Ara-C or methotrexate, potentiation of the T-lymphotoxic effect failed to occur, suggesting that neither drug was acting through inhibition of ADA or PNP. Neither dATP nor dGTP was found to accumulate in cells exposed to methotrexate, with or without additives. In the case of Ara-C, however, 3- to 5-fold accumulations of dATP and dGTP occurred. Thus, we cannot exclude the possibility that the toxicity of Ara-C may be mediated, at least in part, by the accumulation of either dATP or dGTP.

Chlorambucil and azathioprine were highly toxic for both $\mathrm{T}$ and $\mathrm{B}$ cells. In each case, however, the toxic concentration of the drug exceeded human plasma levels attained after therapeutic oral doses $[36,37]$. Therefore, the toxicity of these two agents in cell culture under the conditions of our experiments may bear little relationship to their effects in vivo. Chlorambucil was selectively more toxic for $T$ than B cells. However, further experiments failed to demonstrate any enhancement of $T$ cell killing by chlorambucil in the presence of the deoxynucleoside substrates for ADA or PNP or with deoxycoformycin, and neither dATP nor dGTP levels were elevated in the presence of chlorambucil or azathioprine.

Cyclophosphamide was also found to be more toxic for $\mathrm{T}$ than $\mathrm{B}$ lymphoblasts, but only at high concentrations far exceeding known human plasma levels $[38,39]$. Following administration to patients, cyclophosphamide is metabolized in the liver to the active form of the drug $[40,41]$. This metabolic conversion may not be efficient in the $T$ and $B$ lymphoblasts used in our culture system, which may in part explain the relatively high drug levels required to inhibit the growth of cultured lymphoblasts. The $T$ cell toxicity of cyclophosphamide was not potentiated by the addition of either deoxyadenosine, deoxyguanosine, or deoxycoformycin, and no significant intracellular accumulation of either dATP or dGTP was noted under these conditions.

The experimental immunosuppressive agent, oxisuran, was also shown to be selectively toxic for $\mathrm{T}$ cells in our cell culture system. This finding correlates with previous animal studies which demonstrate the selective cellular immunosuppressive effects of this drug, with sparing of humoral immune responses $[21,42,43]$. Human plasma levels of oxisuran have not been reported but, in our cell culture system, the toxic concentration of oxisuran was found to be high relative to the other drugs studied. Additive experiments failed to demonstrate any potentiation of $\mathrm{T}$ cell toxicity, and $\mathrm{dATP}$ and dGTP levels remained unchanged.

The cell culture and assay system developed in this investigation should prove useful for the identification of new lymphotoxic and $\mathrm{T}$ or $\mathrm{B}$ cellspecific immunosuppressive drugs. Agents found by our methods to be highly lymphotoxic would hold potential as drugs capable of modulating immune function. However, agents found to be relatively non-cytotoxic should not be excluded as possible in vivo immunosuppressants because our system does not control for all potential routes of in vivo drug activation. An important advantage of the in vitro lymphoblast model system for the study of immunosuppressive agents utilized in the present investigation is that it can provide insights into the mechanisms of action of pharmacological compounds at 
the biochemical level. Indeed, this approach has enabled us to demonstrate that none of a variety of currently available immunosuppressive agents functions by inhibiting ADA or PNP, or by causing intracellular dATP or dGTP accumulation by other mechanisms.

Acknowledgements-This research was supported by grants from the National Institutes of Health (AM19045 and CA26284).

\section{REFERENCES}

1. E. R. Giblett, J. E. Anderson, F. Cohen, B. Pollara and H. J. Meuwissen, Lancet II, 1067 (1972).

2. H. J. Meuwissen, B. Pollara and R. J. Pickering, J. Pediat. 86, 169 (1975).

3. E. R. Giblett, A. J. Ammann, D. W. Wara, R. Sandman and L. K. Diamond, Lancet I, 1010 (1973).

4. J. W. Stoop, B. J. M. Zegers, G. F. M. Hedrickx, L. H. Siegenbeek van Heukelom, G. E. J. Staal, P. K. deBree, S. K. Wadman and R. E. Ballieux, New Engl. J. Med. 296, 651 (1977).

5. M. S. Coleman, J. Donofrio, J. J. Hutton, L. Hahn, A. Daoud, B. Lampkin and J. Dyminski, J. biol. Chem. 253, 1619 (1978).

6. A. Cohen, R. Hirschhorn, S. D. Horowitz, A. Rubinstein, S. H. Polmar, R. Hong and D. W. Martin, Proc. natn. Acad. Sci. U.S.A. 75, 472 (1978).

7. A. Cohen, L. J. Gudas, A. J. Ammann, G. E. J. Staal and D. W. Martin, J. clin. Invest. 61, 1405 (1978).

8. J. M. Wilson, B. S. Mitchell, P. E. Daddona and W. N. Kelley, J. clin. Invest. 64, 1475 (1979).

9. B. Ullman, J. D. Gudas, S. M. Clift and D. W. Martin, Proc. natn. Acad. Sci. U.S.A. 76, 1074 (1979).

10. B. S. Mitchell, E. Mejias, P. E. Daddona and W. N. Kelley, Proc. natn. Acad. Sci. U.S.A. 75, 5011 (1978).

11. D. A. Carson, J. Kaye and D. B. Wasson, J. Immun. 126, 348 (1981).

12. D. A. Carson, J. Kaye, S. Matsumoto, J. E. Seegmiller and L. Thompson, Proc. nam. Acad. Sci. U.S.A. 76, 2430 (1979).

13. R. L. Wortmann, B. S. Mitchell, N. L. Edwards and 1. H. Fox, Proc. natn. Acad. Sci. U.S.A. 76, 2434 (1979).

14. I. S. Kazmers, B. S. Mitchell, P. E. Daddona, L. L. Wotring, L. B. Townsend and W. N. Kelley, Science 214, 1137 (1981).

15. J. Bach, The Mode of Action of Immunosuppressive Agents, Chap. 3 and 4. North-Holland, Amsterdam (1975).

16. G. D. Gray, Ann. N.Y. Acad. Sci. 255, 372 (1975).

17. A. Mansour, J. A. Henderson and D. S. Nelson, Clin. exp. Immun. 34, 393 (1978).
18. M. C. Berenbaum and M. B. Lond, Lancet II, 1363 (1964).

19. E. Nordman, H. Saarimaa and A. Toivanen. Cancer 41, 64 (1978).

20. M. S. Mitchell and R. C. DeConti, Cancer 26, 884 (1970).

21. A. E. Fox, D. L. Gawlak, D. L. Ballantyne and H. H. Freedman, Transplantation 15, 389 (1973).

22. M. B. Van der Weyden, R. H. Buckley and W. N. Kelley, Biochem. biophys. Res. Commun. 57. 590 (1974).

23. I. H. Fox, C. M. Andres, E. W. Gelfand and D. Biggar, Science 197, 1084 (1977).

24. P. E. Daddona, J. biol. Chem. 256, 12496 (1981)

25. D. A. Wiginton, M. S. Coleman and J. J. Hutton, J. biol. Chem. 255, 6663 (1980).

26. J. X. Khym, Clin. Chem. 21, 1245 (1975).

27. C. Garrett and D. V. Santi, Analyt. Biochem. 99, 268 (1979).

28. J. Boutagy and D. J. Harey, J. Chromat. 146, 283 (1978).

29. R. W. Bury and P. J. Keary, J. Chromat. 146, 350 (1978).

30. R. J. Hayman, H. Fong and M. B. Van der Weyden, J. Lab. clin. Med. 93, 480 (1979).

31. E. Arons, S. P. Rothenberg, M. daCosta, C. Fischer and P. M. Iqbal, Cancer Res. 35, 2033 (1975).

32. G. A. LePage and J. P. Whitecar, Cancer Res. 31, 1627 (1971).

33. J. J. Coffey, C. A. White, A. B. Lesk, W. I. Rogers and A. A. Serpick, Cancer Res. 32, 1283 (1972).

34. B. L. Hillcoat, M. Kawai, P. B. McCulloch, J. Rosenfeld and C. K. O. Williams, Br. J. clin. Pharmac. 3, 135 (1976).

35. J. L. Cohen and R. E. Brown, J. Chromat. 151, 237 (1978).

36. D. R. Newell, L. J. Hart and K. R. Harrap, J. Chromat. 164, 114 (1979).

37. S. Lin, K. Jessup, M. Floyd, T. F. Wang, C. T. Van Buren, R. M. Caprioli and B. D. Kahan, Transplantation 29, 290 (1980).

38. I. Jardine, C. Fenselau, M. Appler, M. N. Kan. R. B. Brundrett and M. Colvin, Cancer Res. 38, 408 (1978)

39. T. Facchinetti, M. D'Incalci, G. Martelli, L. Cantoni, G. Belvedere and M. Salmona, J. Chromat. 145, 318 (1978).

40. M. Colvin, C. A. Padgett and C. A. Fenselau, Cancer Res. 33, 915 (1973).

41. T. A. Connors, P. J. Cox, P. B. Farmer, A. B. Foster and M. Jarman, Biochem. Pharmac. 23, 115 (1974).

42. H. H. Freedman, A. E. Fox, J. Shavel, Jr. and G. C. Morrison, Proc. Soc. exp. Biol. Med. 139, 909 (1972).

43. F. M. Wilson, G. Smolin, W. B. Jackson and J. M. Hall, Ann. Ophthal. 10, 283 (1978). 